\title{
EMPLOYEE CHOICE AND SOME PROBLEMS OF RACE AND REMEDIES IN REPRESENTATION CAMPAIGNS
}

THE National Labor Relations Board in its zeal to ensure a reasoned choice by employees in representation elections has created a distinction between emotional and rational campaign propaganda on the subject of race. While a closer consideration of the requirements of a free choice suggests that this distinction is not a tenable one, other remedies, not used to date by the Board, seem appropriate in ensuring both a free and reasoned choice in representation elections generally. This Note will address itself to both of these problems.

\section{Race and Reasoned Choice in Representation Caarpaigns}

A union conducts a representation campaign in a southern, non-unionized plant; the employer, seeking to persuade his employees to reject the union, attacks the union as favoring and pursuing a policy of racial integration. ${ }^{1}$ Such attacks on union racial policy, whether blatant or in more subtle forms, have been pressed vigorously in Southern locales ${ }^{2}$ and thus have posed a significant obstacle to unionization in the South. ${ }^{3}$ Though the general failure of organiza-

1. Altering the question that the employees regard as having been put to them will alter their response. For example, it is a principle of public controversy that "the party" which is able to make its definition of the issues prevail is likely to take over the government. . . The substitution of conflicts is the most devastating lind of political strategy:" Schattschnemer, Semit Sovereign People 74, 76 (1960). On the uses of the substitution strategy see also Allport, THe Nature of PrEjudice 410-23 (1954).

2. Attempts to show that unions will favor Negroes are made before nearly every representation election conducted by the NLRB in the South, N.Y. Times, Nov. 10, 1957, p. 57, col. 2. See also H. R. Rep. No. 75142, 87th Cong., 1st Sess. 54 (1961).

In light of the scarcity of authoritative information on the use of the race issue the Yale Law Journal attempted to survey unions and civil rights organizations active in the South. The president of the North Carolina State AFL-CIO wrote that "95\% of the employers in the South raise the racial issue in . . organizing campaigns." Letter from W. M. Barbee to the Yale Laze Journal, February 17, 1963, on file in Yale Law Library. The Public Relations Director of the South Carolina Labor Council, noting that "exact figures are not available," wrote that "the equal opportunity policies and practices of organized labor are very often raised by the employer." Letter from Clarence T. Easterling to the Yale Lotv Journal, February 21, 1963, on file in Yale Law Library.

3. See Troy, The Growth of Union Membership in the South, 1939-1953, 24 S. Eco. J. 407 (1958). The employer's use of the race issue has been credited with the cancellation of some organizational drives, N.Y. Times, Nov. 10, 1957, p. 57, col. 2, and the general failure of all organizational efforts in the South, N.Y. Times, Sept. 23, 1957, p. 38, col. 2. See generally Mirlis \& Brown, Frour Wagner Act to TAFt-HArtuey 125-28 (1950) and Wyle, Union Organization Activity under Taft-Hartlcy, 11 N.Y.U. Conferexce os LABOR 191, 205-10 (1958). But see Marshall, Some Factors Infficencing the Grotuth of Unions in the South, 13 Industrial Relations Research Association, Proceedrngs 166 (1960) (hereinafter IRRA, Proceedrngs). 
tional efforts ${ }^{4}$ is undoubtedly a result of a complex of factors, including hostile local laws, ${ }^{5}$ widespread community and employer antagonism, ${ }_{2}{ }^{6}$ the unfamiliarity of employees with organized activity, ${ }^{7}$ a general labor surplus, ${ }^{8}$ and rising wages

4. Recent history suggests that the problem of Southern union organization is similar to that faced by unions across the country before 1933, Barkin, Organisation of the Unorganized, 9 IRRA, ProceEdrNas 232 (1956). See also Mulus \& Brown, op. cit. supra note 3 , at 126.

While there has been considerable industrial growth in the South and union organization efforts there have been intensive, the growth of unions has been negligible. Leaders of the New South have long since urged that the region's salvation lies in industrialization; cvery Southern state now has a program to attract industry. Marshall, supra note 3, at 180. Between 1939 and 1952 the Southern states were among the leaders in the growth of industrial employment, Wolfbein, The Changing Geography of American Indistry, 6 IRRA, Proceedrngs 202, 203 (1953). See also Van Sickle, Industrialization and the South, 15 S. Eco. J. 412 (1949), and for a still earlier but classic study, see BERGLUnd, STARNES AND DE Vyver, LABor IN THE INDUSTRIAL South 10 (1930). In the immediate postwar era the CIO undertook "Operation Dixie". Since then many unions have applied themselves assiduously and generously to organizing the South. Barkin, supra. For estimates of expenditures and effort see Marshall, supra at 166, n.1. Union efforts have not been notably successful; $17 \%$ of the union potential is presently organized in the South Atlantic states, $18 \%$ in the South Central states as compared with $42 \%$ in the East North Central and $46 \%$ in the Pacific states. Brown, Organization of the Unorganized, 9 IRRA, ProceEdinas 230 (1956). For a table of comparative union membership see de Vyver, Labor Factors in the Industrial Development of the South, 18 S. Eco. J. 189, 194 (1951). The most complete study is Troy, supra note 3 , at 407.

Part of the failure of union efforts in the South is due to the internal problems of the unions, i.e., jurisdictional disputes and the unavailability of funds to meet the high cost of organization in the geographically diffuse Southern industry. Barkin, supra.

5. Notably right to work laws; Barkin, The Decline of the Trade Union Movement and What Can Be Done About It, 1961 Center for the Study of Democratic InstituTroNs 30 (1961).

6. Employers have made a public regional cause of keeping unions out. They have used economic power to destroy the union's following, to discriminate against union leaders, sympathizers and members, and to close mills where the union has gotten a foothold. Local community forces have been marshaled in anti-union campaigns. Mrtus \& Brown, op. cit. supra note 3, at 125-28. See also Marshall, supra note 3, at 174, 176.

"Community hostility to unions in the South is due not only to a natural antipathy for the upsetting influence of a new power center, but also to the effects most Southern leaders think unions have on industrial development."

Marshall, sipra note 3 , at 180 . See also Barkin, The Personaltty Profile of Southenn TeXTILE Workers ( ). Butt cf. de Vyver, sutpra note 4, at 195.

7. Southern laborers are individually oriented and have been reared in agricultural rural societies with little experience with participation in social or collective organization. They have lived in small towns usually isolated and culturally unrelated to metropolitan areas ... they have little personal knowledge of the forms or methods of self-organization and the potential gains to be obtained from workers' unions.

Barkin, Nevo Labor Relations Policies and Remedies Suggested by Different Industrial Settings, 15 IRRA, PRoceEdings (1962) (to be published). Thus the workers are susceptible to the familiar myths, if myths they be, of local dependence on the employer and the plight of Southern industry, and to the dominant parochialism and prevailing attitudes on race. Barkin, Organization of the Unorganized, supra note 4, at 233. See also Marshall, supra note 3 , at 174 .

8. There are a million more workers on Southern farms than are needed, Robock and Peterson, Fact and Fiction About Southern Labor, 32 HARv. Bus. REv. 79, 81 (1954), and 
in the absence of unionism, ${ }^{9}$ the fear of "undesirable" union racial policies ${ }^{10}$ is recognized as a dominant barrier to union success. 11 Two recent decisions 12 of the NLRB have sought to fashion criteria for determining when such racial appeals will require invalidation of the results of an election. ${ }^{13}$ In setting aside a union defeat in one election and declining to do so in another, the Board stated that its test was whether the employer's propaganda created an atmosphere in which "the uninhibited desires of the employees can not be determined."14 The Board upheld the employer's racial appeal in Allon-Morrison Sign Co., deeming it "temperate in tone, . . . germane, and . . . factual" ;" in Sewell Mfg. Co. it found the employer's propaganda so "inflammatory" as to make "a reasoned basis for choosing a bargaining representative" impossible. 10

At one time there was little doubt that one of the NLRB's principal functions was the encouragement and promotion of union organization. ${ }^{17}$ The TaftHartley Act, designed to restore a balance between labor and management, ${ }^{18}$ however, expressly guaranteed to employees the "right to refrain" from collective bargaining ${ }^{19}$ and to employers the right freely to address their em-

low wage, labor intensive, competitive industry comprises a greater part of industry in the South than elsewhere. S. REP. No. 2830, 84th Cong., 2d Sess. 21 (1956).

9. Barkin, Organization of the Unorganized, supra note 4, at 175.

10. For a discussion of union policies on racial matters see MIarshall, supra note 3 , at 180. See also Fleischman, Labor and the Civil Rights Revolution, 43 THE NEW LEADER 16 (1960).

There is some disagreement about the effect of unionization on the Negro. Dewcy asserts that a successful organizational drive would end Negro prospects in Southern manufacturing for many years. Dewey, Negro Employment in Southern Industry, $60 \mathrm{~J}$. PoL. Econ. 279 (1952). Ruchames cites the growth of industrial unions in the South as a factor favoring equality of opportunity there. Ruchaxres, RACE, Jobs AND Poumtes 191 (1953). There was a time when Negro leadership believed that the Negro's main hope was in "solidarity with labor." MYYrdal, AN AMrerican Dilearara 788 (1944).

11. Cf. authorities cited note 3 supra.

12. Seweil Mfg. Co., 138 N.L.R.B. No. 12 (1962). 50 L.R.R.M. 1532 (1962); and Allen-Morrison Sign Co., Inc., 138 N.L.R.B. No. 11 (1962), 50 L.R.R.M. 1535 (1962).

13. Ordering a new election is the exclusive remedy employed by the Board in representation cases, except where the offensive conduct found to be coercive and the evidence for the finding is either non-speech conduct or speech amounting to a threat or a promise, $c f$. text accompanying notes 88-93 infra.

14. Sewell Mfg. Co., 50 L.R.R.M. at 1534.

15. Allen-Morrison Sign Co., 50 L.R.R.M. at 1535, 1536.

16. Sewell Mfg. Co., 50 L.R.R.M. at 1534 .

17. The governing declaration of policy reads in the Taft-Hartley Act as it did in the Wagner Act:

It is [the] declared ... policy of the United States to eliminate the causes of certain substantial obstructions to the free flow of commerce ... by encouraging the practice and procedure of collective bargaining...

49 Stat 449 (1935), 29 U.S.C. $\$ 151$ (1958). But the force of this declaration was substantially greater before the Taft-Hartley amendments. For an indication of how seriously the Wagner Act Board took its duty to affirmatively encourage union organization, see Cox, Some Aspects of the Labor Management Relations Act, 1947, 61 HARv. L. REv. 1, 3-4 (1947). See also Minlis \& Brown, op. cit. supra note 3, at 3.

18. Cox, supra note 17 , at 44 .

19. 61 Stat. 140 (1947), 29 U.S.C. § 157 (1958). 
ployees so long as their speech does not include threats or promises. ${ }^{20}$ Since Taft-Hartley the Board's role has apparently become that of a disinterested umpire of the contest between labor and management for the workers' votes, ${ }^{21}$ its statutory charge being no longer the union, but the employee.22 Thus, while the Wagner Act Board held employers to strict neutrality in representation campaigns, ${ }^{23}$ the employer is now allowed, ${ }^{24}$ indeed encouraged, ${ }^{25}$ to present the case against unionism in order that the employee, in making his choice, may have the benefit of the views and information of all parties to the election. ${ }^{26}$ The fact that a given employer practice tends to inhibit union organization is not a sufficient ground for Board intervention in a representation camm paign. ${ }^{27}$

This increased concern for the conditions under which an employee exercises his choice is reflected in the Board's formulation and development of the "laboratory" concept, which was first announced in General Shoe Corp., ${ }^{28}$ a case decided shortly after Taft-Hartley. In that case the Board found that interrogation of employees in their homes and in the employer's office prior to an election interfered with the employees' "free" choice and thus warranted ordering a new election. ${ }^{29}$ The Board stated that its function was "to provide a laboratory where, under as nearly ideal conditions as possible, the unin-

20. 61 Stat. 140 (1947), 29 U.S.C. \& 158(c) (1958). These amendments and the new section 8 provisions subjecting the organizational activities of labor unions to restrictions similar to those imposed on the activities of the employer, 61 Stat. 140 (1947), 29 U.S.C. \& 158(b) (1958), support the conclusion that the Taft-Hartley Act represents an abandonment of the policy of affirmatively encouraging the spread of collective bargaining.

21. See Cox, supra note 17 , at 44, 274; Mrlurs \& Brown, op. cit. supra note 3 , at 655 ; and Cox, Law and the National Labor Policy 39 (1960).

22. See Cox, supra note 17, at 47, and MrLurs \& Brown, op. cit. supra note 3, at 665 . If the Landrum-Griffin Act can be said to have had any effect on these matters, it is surcly one of reinforcing the concern for the employees. 73 Stat. 519 (1959); 29 U.S.C.A. $\$ 401$ (Supp. 1962).

23. See, e.g., Ford Motor Co., 14 N.L.R.B. 346 (1939), enforced as amended, 114 F.2d 905 (6th Cir. 1940), cert. denied, 312 U.S. 689 (1941). See also 12 NLRB ANN. REp. 17 (1947).

24. See, e.g., Charroin Mfg. Co., 88 N.L.R.B. 38,40 (1950). See also 16 NLRB ANn. REP. $132-33$ (1951).

25. See, e.g., NuTone, Inc., 112 N.L.R.B. 1153 (1955), modified, 243 F.2d 593 (1957), rev'd on other groumds, 357 U.S. 357 (1958). See generally Mulus \& BRown, op. cit. supra note 3 , at 526 .

26. See Cox, supra note 17 , at 15. For a discussion of the Board's varying attitudes toward employer speech, see Wirtz, The New National Labor Relations Board, Hercin of "Employer Perstasion," 49 Nw. U. L. Rev. 594 (1954) ; Sinsheimer, Employer Free Specch, A Comparative Analysis, 14 U. CHr. L. REv. 617 (1947).

27. This fact, secured by the Taft-Hartley Act, had been accepted by the late Wagner Act Board. See Millis \& Brown, op. cit. supra note 3, at 178-89.

28. 77 N.L.R.B. 124 (1948). The considerations finally made explicit here as the laboratory test had been developing through many cases. See, e.g., P. D. Gwaltney, Jr. and Co., 74 N.L.R.B. 371 (1947); Maywood Hosiery Mills, Inc., 64 N.L.R.B. 146 (1945).

29. 77 N.L.R.B. at 127. 
hibited desires of employees can be determined."30 Under the laboratory standard the Board has invalidated elections where it found that the employees have been threatened, pressured or intimidated ${ }^{31}$ or that material facts peculiarly within a party's knowledge have been misrepresented by that party. ${ }^{32}$ It is perhaps just a lag in articulation, rendered innocuous by the fact that the Board has long addressed a host of considerations other than absence of coercion under the guise of protecting a "free choice," 33 that only now in Sewell has a concern for "reasoned choice" been explicitly noted. Here the laboratory concept was articulated as a standard designed to insure that employees were free "from all elements which prevent or impede a reasoned choice."34

An evaluation of the laboratory concept, especially as applied to the injection of the race issue into organizational campaigns, requires a closer examination of what it is meant to ensure-a reasoned choice. A choice is deemed rational or reasoned, if given the goal of the actor, however acquired, and the information before him, he selects that alternative which is most consistent with his goal..$^{35}$ The following model, while not intended to suggest the precision of mathematics, should provide a valuable tool for examining the elements of rationality. ${ }^{36}$ Choosing a union has positive and negative consequences for the employee. An employee's expectations on wages, job security, fellowship, employer attitude, and racial relationships will often be among the principal positive and negative components of the employee's decision to vote for or against a union. ${ }^{3 \pi}$ The ultimate decision will be a function of the value he assigns to each component and the likelihood he attaches to the occurrence of

30. Ibid.

31. See, e.g., Shovel Supply Co., 121 N.L.R.B. 1485 (1958).

32. See, e.g., United States Gypsum Co., 130 N.L.R.B. 901 (1961).

33. In General Shoe Corp., the Board had characterized the employer's conduct as "far beyond the presently accepted custom of campaigns directed at employecs' reasoning faculties." 77 N.L.R.B. at 127. In the series of misrepresentation cases the Board has been concerned with the ability to "evaluate propaganda." See, e.g., United Aircrait Corp., 103 N.L.R.B. 102 (1953). The Board has also promulgated a series of rules designed to insure calm and order at the polling place. See, e.g., New York Shipping Ass'n, 10 S N.L.R.B. 137 (1954). The Board has attended to these various considerations under the rubric of "free choice."

34. Sewell Mfg. Co., 50 L.R.R.M. at 1534.

35. Weber, The Theory of Soctal and Econoumc Organization, 16, 92 (1947). See also Dagl \& Lindbloxr, Polmtics, Economics and Welfare 38 (1953); Srusor, Adamnistrative BeHavior 61-78 (2d ed. 1957) ; Freund, Rationality in Judicial Decisions, paper delivered at 1963 annual meeting of the American Society for Political and Legal Philosophy and to be published in FrIEDricr (ed.), Nossos V (1963).

36. Compare Hempel, Rational Action, in Procezdrngs and Adpresses of the ArrertCan Philosophical Association 9 (1962).

37. "The society and respect of other people" and "creature comforts and economic security" are significant considerations impelling a worker to join a union. Bakke, Why Workers Join Unions, in Shister, Readings in Labor Econosics and Industrial. RELATIONS 30 (2d ed. 1956). 
each. ${ }^{38}$ The following chart is an example of one possible set of values and probabilities.

\begin{tabular}{|c|c|c|c|c|c|}
\hline COMPONENTS & WAGES & $\begin{array}{c}\text { Job } \\
\text { SECURITY }\end{array}$ & FELLOWSHIP & $\begin{array}{l}\text { EMPLOYER } \\
\text { ATTITUDE }\end{array}$ & $\begin{array}{c}\text { RACIAL } \\
\text { RELATIONSHIP }\end{array}$ \\
\hline utility & +80 & +40 & +10 & -20 & -60 \\
\hline probability & (.8) & $(.5)$ & (.5) & $(.5)$ & $(.8)$ \\
\hline $\begin{array}{l}\text { expected } \\
\text { utility of } \\
\text { each componen }\end{array}$ & 64 & 20 & 5 & -10 & -48 \\
\hline $\begin{array}{l}\text { total expected } \\
\text { utility }\end{array}$ & & & +31 & & \\
\hline
\end{tabular}

Given an employee's belief that the above consequences would flow from unionization and the indicated values he attributes to these consequences, an employee decision to select the union, in response to the net positive value, may be deemed a rational choice. ${ }^{39}$ Of course an employee before voting for or against a union does not create such a mathematical quagmire. But he cloes attempt to predict the probable results of unionization and evaluate these results. This process, save for the numbers, is what is described in the above chart.

There are three classes of employer statements that affect the employee's evaluation of the above and other factors and thereby affect his tultimate decision to accept or reject the union. One class of employer speech, orclinarily termed coercive, clearly impedes a reasoned choice. The National Labor Relations Act proscribes any employer action which is undertaken for the purpose of deterring organizational and collective activities. ${ }^{40}$ Thus, for example, a wage increase in appreciation of a rejection of a union would clearly be an unfair labor practice. ${ }^{41}$ Since the employer cannot take these actions he cannot discuss them during an organizational campaign, for such speech would lead the employees to place a disutility on unionization that is not justified. Thus it is to be expected that such speech constitutes grounds for invalidating the election as well as an unfair labor practice. ${ }^{42}$ Such threats or promises of employer action should not be confused, however, with the employer's description of events that are beyond his control. The indefiniteness of the line between events within and beyond the employer's control is demonstrated by the Board's difficulty in preventing the distinction between an unlawful threat or

38. For a careful discussion of the process of attaching utilities and probabilitics to events see Luce \& Ratffa, Games and Decisions (1957), and Davidson, Suppes \& Steger, Deciston Making: An Experimental Approach (1957).

39. For a lucid statement and comparative analysis of the many criteria, here simplificd, for determining which course of action conduces most appropriately to the desired end sce LUCE \& RAIFFA, op. cit. supra note 38, at ch. 13; also DAHL \& Lindalom, op. cit. supra note 35 , at $57-92$.

40. 61 Stat. 140 (1947), 29 U.S.C. $\$ 158$ (a) (1) (1958).

41. Cf., e.g., Top Mode Mfg. Co., 97 N.L.R.B. 1273, 1275-76 (1952).

42. See, e.g., Franchester Corp., 110 N.L.R.B. 1391 (1954). 
promise and a lawful prediction from becoming a semantic one. ${ }^{23}$ Nevertheless, the distinction is a necessary one. Although an employer's speech is culpable if employees may legitimately infer that the undesirable event is within the control of the employer, ${ }^{44}$ speech about the consequences of unionization that is not within his control is permissible and indeed encouraged. ${ }^{6}$ Thus a statement to his employees that he will hire Negroes "if the union is elected" is coercive," while a suggestion that the union will bring Negroes into the plant with it is not. ${ }^{4 \pi}$

The goal of a fully rational decision will be attained only if there is a maximum likelihood that the actor will know the facts that cast light on the alternatives and consequences. A choice may thus be deemed more or less rational depending on the extent and accuracy of the information which serves as the foundation of the decision. ${ }^{48}$ If, for example, the employer misinforms the workers as to the union's success in raising wages elsewhere, thus leading them erroneously to conclude that their wages will remain the same, and thereby to attribute a value of " $\mathrm{O}$ " to this component, their opportunity for a reasoned choice is diminished.

Although the Act does not explicitly require accurate or full information, the NLRB has recognized the importance of accurate information to a reasoned decision. Thus, the Board has invalidated elections preceded by material misstatements of facts peculiarly within the speaker's knowledge. ${ }^{40}$ Particularly illustrative of the Board's treatment of misrepresentation in a racial context is Heinzt Division, Kelsey Hayes Co. ${ }^{50}$ in which one of the campaigning unions

43. Cf., Sovern, The National Labor Relations Act and Racial Discrimination, 62 CoLuM. L. REv. 563, 576-78 (1962). The distinction between a threat or a promise and a prediction was announced in Chicopee Mffg. Co., 107 N.L.R.B. 106 (1953). Compare Murray Ohio Mfg. Co., 122 N.L.R.B. 1305 (1959). The distinction has not been involed by the Kennedy Board.

44. Cf. Smith Rice Mill, Inc., 88 N.L.R.B. 959 (1950).

45. See notes 24-25 supra.

46. Petroleum Carrier Corp. of Tampa, 126 N.L.R.B. 1031 (1960).

47. Sharnay Hosiery Mills, Inc., 120 N.L.R.B. 750 (1958).

There was a time when any mention of the union's policy on race was regarded as an unfair labor practice, but since 1949 such remarks, much as they have been deprecated, have been allowed by the Board. Compare Edinburg Citrus Ass'n, 57 N.L.R.B. 1145 (1944) ("If the CIO comes in the Mexicans will soon have your job." Id. at 1156.), and Bibb Mffg. Co., 82 N.L.R.B. 338 (1949) ("You can join the union if you want to work with Negroes." Id. at 358.) with American Thread Co., 84 N.L.R.B. 593 (1949) ("You will work side by side with Negroes sharing the same rest rooms. Id. at 601) and Happ Bros. Co., 90 N.L.R.B. 1513 (1950) ("... [D]on't you know if you all get the union up here you'll be sitting up here by niggers?" Id. at 1533.).

48. See Kelley, Political Campaigning 10 (1960); Soron, op. cit. supra note 35 at 75-76 ("objectively rational behavior"). But cf. Hempel, stpra note 36, at 6 .

49. See, e.g., United States Gypsum Co., 130 N.L.R.B. 901 (1961). See also 25 NLRB ANN. REP. 52 (1960).

50. 126 N.L.R.B. 151 (1960). The fact that this misrepresentation of union race policy occurred in Philadelphia, Pennsylvania indicates that the problem of an cmployer's use of race propaganda is by no means restricted to the South. 
hired Negroes to distribute the literature of the competing union at an em. ployee baseball game. The Board, in invalidating the election of the union that hired the Negroes, apparently recognized that one requirement of the customary misrepresentation rule-that the misstatement be of facts within the speaker's peculiar knowledge-was inappropriate for misrepresentations of racial policy. ${ }^{51}$ Even though the misrepresented policy is not within the special knowledge of the employer or competing unions (certainly a union knows what its racial policy actually is), the union's ability to persuade the employees of the truth, and thus to alter the change in utilities attributable to the misrepresentation, cannot be relied upon. ${ }^{62}$ Where a subsequent clarification is not likely to dissipate quickly the effects of such misrepresentation, invalidation of the election and perhaps a bar to a new election for a stipulated period of time are appropriate, albeit not wholly effective, measures for ensuring a rational choice.

There are two ways in which the employer without resorting to "coercive" or untrue statements may lead his employees to reject the union. One would be to inform the workers of consequences of unionization that they had been unaware of and upon which they place a negative value. For example, the employees may have previously forecast three consequences of a pro-integra. tion union, each having a utility of -20 , and the employer informs them of two other consequences, which leads them to place a total utility of -100 on this component. ${ }^{53}$ Although it may decisively affect the employee's decision, this statement of a possible consequence of unionism cannot be deemed a coercive threat or promise, since it describes a matter that is not within the employer's control. Indeed knowledge of the consequences of organization increases the employees' opportunity for rational choice. ${ }^{54}$ The second way would be to argue about the values the employees should assign, either explicitly or by stating the consequences in value laden terms. An environment conducive to a fully rational choice would be one in which the employees not only had full and accurate information but also an opportunity to hear full argument about values and to weigh such arguments calmly and carefully. ${ }^{.5}$

There are certain appeals which stimulate the emotional processes in such a way as to make dispassionate deliberation impossible or at least unlikely. If these appeals could be identified and isolated, the appropriate remedy to ensure an opportunity for rational choice would be to prohibit such speech. The diff-

51. Id. at 153. See also 25 NLRB ANn. REP. 52 (1960).

52. The difficulties in reaching biased individuals with "the facts" on racial matters is indicated in Cooper \& Jahoda, The Evasion of Propaganda, How Prejudiced Pcoplc Respond to Anti-Prejudice Propaganda, in Katz, Cartwright et al., Pundic Orinion and Propaganda 313 (1954). See also Katz, Psychological Barricrs to Commutication, in Scaramar, Mass Communications 275 (1949). But cf. Group for the Advancement of Psychiatry, Emotional Aspects of Schoor Desegregation 20-37 (1960) (hereinafter cited as GAP). (It is possible, though difficult, for the attitudes of biased people to be changed.)

53. See model in text accompanying notes 36-39 supra.

54. Se conception of rationality in text accompanying note 49 supra.

55. See the suggestive remarks of OppenheIM, Dinensions of Freedon 17-18 (1961). See also Simon, op. cit. supra, note 35 at 75-76 ("deliberately rational behavior"). 
culty, beyond the fact that the employer has a right to speech and the employees, quite like voters in political elections, are free to choose on emotional grounds, is that argument about some issues, regardless of the manner of presentation, evokes emotional responses. ${ }^{56}$ However valid the common sense distinction between a rational appeal and an emotional appeal, between "a calm, orderly, restrained presentation" and "a complex fusion of excitement, resentment, vague enthusiasm, strangely aroused fears and hopes," to issues where, owing to the nature of the issue itself, the predictable response of any appeal is primarily emotional. Racial attitudes, especially in the South, are held with a fervor quite like religious and political convictions. "s While such attitudes may also be founded upon sustained value preferences, ${ }^{30}$ the fundamental difficulty in applying a common sense distinction between emotional and rational appeals in this area is that no criteria have been derived for ascertaining the nature and form of propaganda which activates emotional rather than rational processes on emotionally charged issues. ${ }^{\text {co }}$ Most appeals to race in the South are likely to call forth a response far more intense and less rational than appeals to wages, hours, and conditions of employment. Moreover, such factors as the social environment, the changes taking place in that environment, and the fervor with which racial attitudes are held are likely to be far more operative factors in determining the nature of the response to arguments about the question than the language or manner in which the argument is presented. ${ }^{61}$ Thus, for example, it is difficult to conceive of any calm and orderly presentation of argument that would have evoked a primarily rational response from many persons in Mississippi to the issue of Mieredith's admission to the University, at least once the issue had become a glowing con-

56. Hovland, Janis \& Kelley, Conarunication and Persuasion 57-60 (1953).

According to Freudian theory emotions are involved in all decision processes. The distinction between rational and irrational processes is not grounded on the presence or absence of emotion but rather on the sort of emotion that is present. The rational processes are characterized by emotional drive relatively bound in structures of a highly socialized nature and discharged in a reflective, controlled fashion. The irrational processes involve emotional drives striving toward immediate release. Schafer, Regression in the Scriec of the Ego: the Relevance of a Psychoanalytic Concept for Personality Assessmem, in Lisozey, Assessarent of Hudran Motrves 119, 123-25 (1958). The suggestion here is not that no distinction can ever be drawn between the rational and irrational treatment of issues. Indeed there are some issues, e.g., wages and hours of employment, that we are used to having discussed on a rational level and irrational appeals on such issues might well be recognizable. The difficulty arises when the issue is such a stormy one as race. Here the attempted distinction does not appear workable.

57. Hartmann, The Comparative Effectiveness of 'Emotional' and 'Rational' Polsical Leaflets, 31 J. ABNorar. Soc. Psychol. 31 (1936).

58. Cf. GAP, op. cit. supra note 53, at 10-20.

59. Cf. GAP, op. cit. supra note 53, at 9-10, 20.

60. Hovland, JANIS \& KeLleY, op. cit. supra note 57, at 58-59. See generally Lassweli \& Lettes, The Language of Polttics (1949) and Berelson, Contenti Axalysis iN CoMarunication Research (1951).

61. See authorities cited at note 52 supra. 
troversy. On the other hand, a demogogic appeal to persons in that state who were differently disposed to the issue would probably not significantly alter the nature of their response. ${ }^{62}$

Sewell and Allen-Morrison represent the Board's maiden voyage into the emotional nature and effect of campaign propaganda. In Sezvell the Board believed that it had identified and isolated "inflammatory" race propaganda and thus invalidated the election;3 similarly, in Allen-Morrison the NLRB believed it had discovered the true nature of a factual, germane and temperate presentation of the union's race policy and upheld the election. ${ }^{\text {ot }}$ The failure of this excursion into a wonderland of prediction and surmise which appears to lie beyond the Board's expertise is borne out by a closer examination of these two cases. A comparison of the propaganda in Sevell with that in AllenMorrison demonstrates the unworkability of the common sense distinction between rational and irrational appeals as applied to such emotionally laden is. sues as race.

The election in Sezvell Mfg. Co. took place in two small towns in Georgia. ${ }^{\text {of }}$ During a campaign by the Amalgamated Clothing Workers of America, AFL-CIO, the employer, two weeks before the election, sent each employee a picture of an unidentified Negro man dancing with an unidentified white lady, captioned "The CIO Strongly Pushes and Endorses the [Fair Employment Practices Commission]." The employer also included a reprint of a similar picture which has been published in the Jackson, Mississippi Daily Nows, captioned "Union Leader James B. Carey Dances with a Lady Friend." Later the employer sent a letter calling attention to the union's support of the NAACP and CORE. For four months prior to the election, Militant Truth, a four-page monthly anti-union racist newspaper ${ }^{\mathbf{6 7}}$ carrying articles on "race mixing" and "radical labor union organizers" was included in the literature sent to the employees by the employer.

The election in Allen-Morrison took place in Lynchburg, Virginia. ${ }^{08}$ It was preceded by an employer campaign which included a mailing eight days before the election of a five-and-a-half page letter, one page of which discussed the union's position on the race question. The employer there quoted from the text of the AFL-CIO brief in Brozen v. Board of Education where the federation wrote that it "supports the elimination of racial segregation from every phase

62. See N.Y. Times, Oct. 1, 1962, p. 22, cols. 6-8. And comparc N.Y. Times, Oct. 1, 1962, p. 23, col. 5 with N.Y. Times, Oct. 1, 1962, p. 24, col. 4.

63. Sewell Mfg. Co., 50 L.R.R.M. at 1535.

64. Allen-Morrison Sign Co., 50 L.R.R.M. at 1536-37.

65. Sewell Mfg. Co., 50 L.R.R.M. at 1532.

66. This picture of James Carey, secretary-treasurer of AFL-CIO, dancing with a Nigerian delegate at an International Labor Organization Conference in Geneva has been given wide circulation whenever his union seeks to organize in the South. H. R. REP. No. 75142, 87th Cong., 1st Sess. 53 (1961).

67. Miltitant Truth is the same periodical circulated in Blue Ridge Shirt Mfg. Co, 70 N.L.R.B. 741, 756 (1946).

68. N.L.R.B. Decides Two Cases Dealing with Racial Propaganda, NLRB Press Release, Washington, No. R-882, August 10, 1962. 
of American Life ... forthwith" and that where "unions have their way, there is likewise no segregation in the use of plant eating places, locker rooms, restrooms, etc." The employer also noted a $\$ 75,000$ AFL-CIO contribution to the NAACP "which is the organization working to wipe out all racial segregation, both in schools, manufacturing plants and elsewhere." The employer stated: "Whether you believe in segregation or integration of white and colored schools, swimming pools, plants and other places is a question for you to decide. . . . The Company considers this a matter for each individual to decide. The national unions on the other hand ... have tried to force [integration] down the throats of people living in the South." Militant Truth, sent two days before the election, reported that the national union had taken over direction of the affairs of a near-by local because the local had voted to buy bonds to help finance a segregated school.

The Board concluded from the evidence in Sewell that the employer prevented a "reasoned" choice by deliberately seeking "to exacerbate racial prejudice and to create an emotional atmosphere of hostility to the [union]."70 It found in Allen-Morrison, however, that the employer had not resorted to inflammatory appeals and therefore had not impaired the employee's reasoned choice. ${ }^{71}$ But if the offensive factor in such campaigns is an appeal that tends to reduce the likelihood of a reasoned or a rational choice, there seems little to distinguish the propaganda in Allen-Morrison from that in Secuell. ${ }^{72}$

Compare, for example, the personalized nature of the propaganda in AllenMorrison with the relatively impersonal propaganda in Sewell. It is well established that content factors which augment the meaningfulness of the propaganda by elaborating on its consequences and by emphasizing its applicability to the audience tend to heighten the intensity of emotional response. ${ }^{73}$ The relatively minimal discussion of the racial issue in Allen-Morrison did not necessarily make it less effective than the full-blown inflammatory propaganda in Sewell. Indeed there is evidence that a strongly phrased or blatant appeal will tend to be less effective than a more temperate presentation. ${ }^{74}$ Therefore, it seems difficult rationally to conclude that an atmosphere less conducive to a reasoned choice was created in Sewell than in Allen-Morrison; if it be judged by its likely effect, the propaganda was as "temperate" or "inflammatory" in one as in the other.

69. Allen-Morrison Sign Co., 50 L.R.R.M. at 1536.

70. Sewell Mfg. Co., 50 L.R.R.M. at 1535.

71. Allen-Morrison Sign Co., 50 L.R.R.M. at 1536.

72. In neither Sewell nor Allen-MForrison did the Board find that the employer's propaganda misrepresented the union's racial policy and the cases therefore cannot be distinguished on those grounds. Neither can they be distinguished by the fact that one election was in Georgia and the other in Virginia. It is doubtful that racial attitudes in Lynchburg are so certainly and significantly different from those in Bremen and Temple to support a judgment that the employer's propaganda there was any less or more inflammatory. Cf. "Jistice in Virginia," The New Republic, March 2, 1963, p. 5 (an editorial account of jury treatment of Negroes in Lynchburg).

73. HoVLAND, JANIS \& KELLEY, op. cit. supra note 57, at 72.

74. Id. at 80-82. 
Given the present state of knowledge about emotional and rational appeals, as well as the numerous variables that the Board does not seem competent to assess, the result of applying the Board's new found distinction in any particular case would seem to be based on speculation. More candidly, the results are likely to turn on such "emotional" factors as the trial examiners' or Board's feelings toward the statements made by an employer during a representation campaign. ${ }^{75}$ This, however, is not to say that some employer arguments on the subject of race do not impair the likelihood of a reasoned choice, but that a distinction between these arguments and others which appeal to deeply held value preferences is not workable. It would follow, then, that the only way to eliminate the first category of arguments is to regard all racial appeals as inflammatory and to prohibit all discussion on the subject. But such an approach would deny employees an adequate opportunity to consider the issue of race in deciding to accept or reject the union. Indeed it would be tantamount to asserting that racial prejudice was an improper reason for rejecting a union. Such an assertion, desirable as it may be, seems inconsistent with the proper role of an administrative agency and more specifically with the statutory obligations of the Board.

By relying on a distinction between rational and irrational appeals to the racial issue, which the Board does not view as unworkable, the NLRB has avoided recognition of the inconsistency between its position in cases involving race propaganda and its fundamental objective of encouraging unfettered employee choice. The Board's duty under sections $7^{70}$ and 9 (c) ${ }^{77}$ is to determine the desires of the employees on the question of union representation; it is nowhere authorized to decree that some employee desires are to be registered and respected and others not. To refuse to recognize the employees' selection requires an assumption that the employees have the freedom to make certain choices and not others. This is not the sort of freedom of choice we are used to thinking of as guaranteed by our institutions. ${ }^{78}$ The freedom of employee choice which the Board has sought to preserve in representation cases generally is not the "positive freedom"79 to choose only those ends the Board or some other institution deems "rational." 80

75. Compare, e.g., the trial examiner's report in Neco Elec. Prod. Corp., 124 N.L.R.B. 481, 485 (1959), with the trial examiner's report in Petroleum Carrier Corp. of Tampa, 126 N.L.R.B. 1031, 1038 (1960).

76. "Employees shall have the right to self-organization, to form, join, or assist labor organizations ... and shall also have the right to refrain from any or all of such activities...." 61 Stat. 140 (1947), 29 U.S.C. $\$ 157$ (1958).

77. "[The Board] shall direct an election by secret ballot and shall certify the results thereof." 61 Stat. 143 (1947), 29 U.S.C. § 159 (c) (1) (B) (1958).

78. See generally BERLIN, Two CoNCEPTS OF LIDERTY (1958) in which the author argues that the sort of freedom central to liberal democratic saciety is the freedom, not to make certain approved choices, but to make any choice. Surely this sort of freedom is crucial to the proper functioning of an election process, for the very point of the clection process is to direct our institutions according to the wishes of the people.

79. This is Isaiah Berlin's phrase.

80. The concept of rationality is conventionally used, as it is in this Note, to characterize some aspect of the coincidence of means to ends. There are some, however, who have 
If a policy of furthering racial integration could be found in the NLRA or other legislative commands, a rule forbidding mention of race in organizational campaigns might be justified. At the least, the existence of such a policy would require evaluation of such a rule in the context of other statutory policies. Neither the statute nor the Constitution, however, charges the Board with the duty of encouraging racial integration. Constitutional commands forbid governmental discrimination on the basis of race; they in no way require affirmative governmental action to integrate the races. While the Board as an agency of government has the primary duty of conforming to constitutional commands, respecting the choice of employees who reject a pro-integration union is far from the affirmative official conduct necessary to sustain a finding of governmental action which denies equal protection. ${ }^{81}$ It might be argued, however, that the recent Board decisions revoking the certification of unions that exclude Negroes from membership in the craft or bargaining unit which they represent ${ }^{82}$ evidence a statutory policy of furthering racial integration. The theory underlying these decisions is that a union has a duty to represent fairly all members of a bargaining unit and that persons excluded from union membership for arbitrary reasons cannot be fairly represented by the union. ${ }^{83}$

suggested that "rationality" might well be used to characterize the ends themselves. Kaplan, for example, in remarks at the 1962 meeting of the American Socicty of Legal and Political Philosophy (see note 35 supra) suggested that rationality involves not only acting so as to achieve the values pursued, but also judging that the ends themselves are worth pursuing. Nagel, at the same meeting, suggested that it is appropriate to talk about rationality of ends, to ask, e.g., whether the choice of ends is warranted. If rationality requires the cvaluation of ends, the difficult question, as Kaplan pointed out, is: where do we get the insight to value ends-how do we judge them without a comprehensive political philosophy. The discussion of rationality of ends leads once more back to Berlin's concept of positive liberty: Berlin sees as central to freedom that no institution should have the power or the authority to formulate and effectuate a comprehensive political philosophy but rather that the individual should be protected in choosing and gaining whatever ends he wishes. No one is to tell the individual (except for argument's sake) that his choice of goals is irrational, and certainly no one is to tell the individual his choice is beyond the pale, except of course where the individual's choice is competing with the choice of another individual and some adjustment is necessary. This theory seems exemplified in democratic elections where an individual may vote as he chooses for whatever reason he chooses (except of course to secure a bribe) whether or not the choice be "warranted" or "worth making" from the vicwpoint of some comprehensive political philosophy. See supra note 78.

81. Compare Shelley v. Kraemer, 334 U.S. 1 (1948). (The parties to the restrictive covenant could not have accomplished their purposes if the state had not ordered compliance with their agreement).

Where ... the parties could have achieved their purposes without the federal enactment ... the federal statute ... does no more than declare that the federal government will "tolerate" the [private activity]. . . . And governmental toleration will not sustain a finding of governmental action.

Wellington, The Constitution, The Labor Union, and "Govermmental Action," 70 YaLE L.J. 345,356 (1961).

82: Hughes Tool Co., Trial Examiner's Report IR-93-63, February 28, 1963. Cf., Pioneer Bus Co., 51 L.R.R.MI. 1546 (1962).

83. Steele v. Louisville \& N.R.R., 323 U.S. 192 (1944); Syres v. Oil Workers, 350 U.S. 892 (1955). See, e.g., Cox, The Duty of Fair Representation, 2 VILL. L. REv. 151 (1957). 
Although this extension of the fair representation doctrine has been exclusively applied to membership exclusion on the basis of race, there is nothing in its rationale to so limit its applicability. Rather it would appear to apply to exclusion of workers on any grounds other than a failure to pay dues or perhaps to comply with legitimate union rules. Thus the rationale of the above decertification cases based upon the statutory duty of fair representation does not indicate that the NLRA imposes an obligation to integrate labor unions. As with most governmental requirements regarding race or other arbitrary classifications, the rationale embodies a negative command not to discriminate. ${ }^{84}$ And the distinction between a duty to integrate and a duty not to discriminate, i.e., not to use race as a criterion for action, is by no means a semantic one. ${ }^{85}$ Indeed the validity of legislation which requires integration, benign qtotas, is not free from doubt. ${ }^{86}$ Thus it requires a leap of feeling, not an inference from reason, to find a policy of promoting racial integration in the NLRA.

Notwithstanding the absence of a constitutional or statutory duty to further racial integration, to what extent may a governmental agency properly seek to advance racial equality along with its other objectives? In terms of democratic theory, it is doubtful that governmental agencies, in the absence of statutory directive requiring or encouraging racial integration, may legitimately pursue this value. Where the validity of this statutory directive, even if one could be found, would be problematical, such a pursuit seems more than doubtful. Moreover, any promotion of racial integration by the Board necessarily involves a cost in terms of other values-those embodied in the specific legislation which the agency is charged with enforcing (freedom of choice) and those rooted in historic cultural experience (freedom of speech and association). Basic principles of representative government dictate that the official resolution of such major value conflicts does not reside in administrative agencies. ${ }^{87}$

\section{Remedies in Representation Campaigns}

The discussion of the Board's approach to racial propaganda suggests not only that its efforts there are ill-conceived but that they are misdirected. If the Board has been perhaps overzealous with regard to race propaganda, it has not been nearly so zealous as it might be in the matter of ensuring rational choice in representation proceedings generally. Even now many appeals to race and other emotionally charged appeals that impair a reasoned choice are permissible. To the extent that ignoring the manner of presentation of the racial issue would further undermine the employees' opportunity for a rational choice, the need for addressing the major question of rationality in representition elections is underscored. The remedies employed to date for misrepresen-

84. Cf. Frank \& Munro, The Original Understanding of "Equal Protection of the Laws," 50 Coluk. L. Rev. 131, 167-68 (1950) ; Tussman \& ten Broek, The Equal Protection of the Laws, 37 CALIF. L. REv. 341, 357 (1949).

85. Coffin, Desegregation: Will It Work?, Saturday Review, Nov. 11, 1961, 1. 20.

86. Cf. Progress Dev. Corp. v. Mitchell, 286 F.2d 222, 230-31 (7th Cir. 1961).

87. See Hart \& Sachs, The Legal Process 183, 187-88 (Mimeo. 1958). 
tation, for lack of opportunity for deliberation, and perhaps for employer coercion are inadequate to ensure a reasoned choice.

The Board's remedial powers are strongest where it finds the employer's conduct to be coercive. In such cases the Board can issue a cease and desist order as well as an order for a new election. ${ }^{83}$ The more usual remedy in representation cases is the invalidation of the election and the ordering of a new election. The Board's authority to issue a cease and desist order against employer speech is restricted by Section $8(\mathrm{c})$, which provides that employer speech may not constitute, or be used as evidence of, an unfair labor practice unless it amounts to a threat or promise. ${ }^{80}$ The legislative history of $S(c)$ indicates that it was designed to guarantee the employer's right of speech, and to ensure that his speech would not be subject to the unfair labor practice remedy of a cease and desist order. ${ }^{90}$ The Board has been able to hold that $S(c)$ imposes no limitation on the sort of conduct that is relevant to representation proceedings precisely because it does not apply the unfair labor practice remedy in that area.91 In cases of misrepresentation the cease and desist order has consistently been omitted from the order for a new election and no retraction has been required.92 The same limitation applies to the remedies invoked to preserve the employees' opportunity for deliberation. In this area the Board has promulgated a series of rules forbidding campaigning at the polls, ${ }^{93}$ and speeches on company time within twenty-four hours of the election. ${ }^{94}$ The only sanction for a violation of these rules is a new election. The offensive language is not of course expunged from the employees' minds and, except for coercive speech, may be repeated by the employer. ${ }^{95}$ Moreover, present remedies neither prevent an atmosphere of confusion, misinformation, and inflammation from developing at the subsequent election campaign, nor increase the extent of the information and argumentation, or the opportunity for deliberation available to employees, except as the passage of time and new efforts by the parties chance to further these objectives. ${ }^{96}$

Since an injunction against misrepresentation and other noncoercive speech is prohibited and a new election order is inadequate to ensure a reasoned choice, it would seem that the most desirable remedy, consistent with an appropriate role for the Board, is one designed to increase rather than decrease speech, insuring an opportunity for full and accurate information, full argument, and deliberation in the electoral process.

88. See, e.g., General Shoe Corp., 77 N.L.R.B. 124, $128-29$ (1948).

89. 61 Stat. 140 (1947), 29 U.S.C. § 158(c) (1958).

90. See authorities cited at note 26 stipra.

91. See Metropolitan Life Ins. Co., 90 N.L.R.B. 935, 938-39 (1950).

92. See, e.g., United Aircraft Corp., 103 N.L.R.B. 102, 107 (1953).

93. See, e.g., Higgins, Inc, 106 N.I.R.B. 845 (1953).

94. Peerless Plywood Co., 107 N.L.R.B. 427,429 (1953).

95. See note 92 stupra. (Note the absence of a cease and desist order.)

96. The N.L.R.B. might order that its opinion be posted. By thus informing the employees of the reason for the new election the confusion, misinformation and inflammation, in part, might be dissipated. 
The significance of open and full discussion in representative campaigns, as in all political campaigns, lies in the fact that it forms the essential basis for a reasoned choice. ${ }^{07}$ Structuring the presentation of views into the form of a debate should enhance the contribution of discussion to such a choice. debating situation two parties advocating alternative courses of action enjoy equal access to an identical audience and equal ability to commtnicate their arguments to that audience. Each asks the audience to favor one of the two proposals, stating the reasons that support the choice of the alternative he recommends. Each seeks to demonstrate that his proposal accords with the principles, goals, and interests of the audience. The debater is under some compulsion to challenge those of his opponent's arguments that express aims or assumptions differing from his own and must answer similar challenges from his opponent. If he does not, he risks suggesting to the audience that his opponent's arguments cannot be met or that his own cannot be defended; if he responds with obvious evasions, the audience may conclude that his case is too weak to be frankly discussed. Moreover, the debating situation contains certain checks on the accuracy of the information presented. A party who distorts the facts risks exposure, for he gives strong incentive to his opponent to point out the distortion.

Given the benefits of confrontation and joinder of issues, the principle objective of the Board in representation campaigns should be to assure equal and maximum union-management access to the employees. Although the decision has not been so read by commentators or the Board, the Supreme Court in $N L R B$ v. United Steelworkers ${ }^{90}$ seems to have endorsed this view of the Board's role. Implying that per se rules regarding access might not be appropriate, it found that the essential factor in organizational campaigns was a balance between the opportunities of union and management to present their views to employees. ${ }^{100}$ Thus the Court indicated that the Board was to examine the available channels of communication in order to determine whether the facilities and resources available to the union for effectively reaching the employees with a pro-union message are as great as the employer's for promoting his views. ${ }^{101}$ This decision might be criticized as leaving the Board without standards for making the determination whether a balance or imbalance exists. ${ }^{102}$ But the Court's decision on the evils of per se rules does not preclude the Board from establishing guidelines through the use of presumptions of imbalance in certain circumstances. ${ }^{103}$ Indeed, to the extent that such guidelines and presumptions insure an unimpeded flow of information to the employees from both the union and management, they wotld appear to follow from the Court's views in United Steelworkers.

97. See MiliL, on Liberty (1859).

98. See KELLEY, op. cit. supra note 48 at 16-25.

99. 357 U.S. 357 (1958).

100. Id. at 363 .

101. Id. at 364.

102. Cf. 357 U.S. at 364. See Note, 57 Micr. L. REv. 615, 618 (1959).

103. See text at note 108 infra. 
Resurrection of the presumption of imbalance embodied in the now discarded Bonzeit Teller doctrine ${ }^{104}$ would go a long way toward ensuring equal access to the union and maximum discussion to employees. Apparently recognizing the relationship between a full presentation of issues by both sides and a reasoned choice, the Board in Bonwit Teller held that an employer committed an unfair labor practice when he addressed his employees during paid company time on his premises without affording the union an opportunity to address the employees in identical circumstances. ${ }^{105}$ A substantial part of the Bonzeit Teller doctrine was short-lived, however, for two years later the Board in Livingston Shirt Co. held that in the absence of either an unlawful broad nosolicitation rule or a privileged no-solicitation rule an employer may, notwithstanding his own pre-election speeches, deny the union the right to address the employees on his premises during company time. ${ }^{100}$ Among the reasons for discarding the Bonwit Teller doctrine was the purported per se quality of a rule requiring an employer to open his premises to the union upon using these premises to address his employees in an organizational campaign. ${ }^{107}$ But a fair reading of the Bonwit Teller doctrine, or in any case the above proposal, would create a presumption of imbalance where the employer has used his premises on company time for an anti-union speech. A refusal to allow the union a similar opportunity would not be an unfair labor practice if the $\mathrm{cm}$ ployer shows that other channels of communication available to the union were equally effective in presenting the union's views to the employees. This presumption, rebuttable in circumstances where there is equal opportunity for communication, would not seem to offend the Court's objections in Unifed Steelworkers to per se rules. ${ }^{108}$ Indeed, to the extent that it ensures an intelligible means of determining whether the opportunities for communication are balanced, it would seem to follow from the Court's views in that decision. ${ }^{103}$ It is true that an employer might rarely be able to make the showing necessary to rebut the presumption, since alternative effective means of communication will probably not often be available. But this is merely to say that the justification for the presumption will be present in most cases. If a case by case balancing process without benefit of the presumption would lead to the same resulta finding of insufficient alternatives and thus an unfair labor practice-to reject a presumption which provides an intelligible guide to employer conduct

104. 96 N.L.R.B. 608 (1951), enforcement den. on other grounds and order remonded, 197 F.2d 640 (2d Cir. 1952), cert. denied, 345 U.S. 905 (1953), modified 104 N.L.R.B. 497 (1953).

105. 96 N.L.R.B. at 612. The Bonzuit Teller holding was stated narrowly: the union must be accorded opportunity to reply on company time and premises where "circumstances are such that only by granting a request [by the union for equal time] will the employees have a reasonable opportunity to hear both sides." Ibid. The rule was applied, however, without much regard to the circumstances. See the cases collected in Livingstone Shirt Corp., 107 N.L.R.B. 400 , at 405 n.12 (1953).

106. 107 N.L.R.B. at 409.

107. Id. at 405 .

108. In fact the Supreme Court in United Steckcorkers referred to the Bonzit Teller rule with seeming approval. 357 U.S. at 364.

109. Cf. 357 U.S. at 364 . 
and which contributes to administrative efficiency would be to sacrifice these benefits for some abstract attachment to unstructured ad hoc balancing.

The other objections found in Livingston Shirt to the Bonwit Teller doctrine, based on the employer's speech and property rights, ${ }^{110}$ are considerably more persuasive and are equally applicable to a presumption as to a por se rttle. The extent to which requiring the employer to open his premises on paid contpany time for union organizers to address his employees imposes a burden on the employer's property rights should not be underestimated. Because this burden is substantial, it is also true that this requirement attaches a fairly weighty condition to the employer's freedom to address his employees. It is no answer to say that the employer need not address his employees, since that would hardly be consistent with the objective of maximizing discussion. Previouts resolutions of these questions have beclouded the competing considerations by a notion that the employer invites the obligation of offering his premises and con1pany time to the union by addressing his employees in such circumstances and that the requirement therefore is justified by his own voluntary action. ${ }^{111}$ If this were the justification of the Bonwit Teller doctrine, its curtailment in Livingston Shirt seems unquestionable.

The justification for the doctrine is, however, far more persuasive. Perhaps the best statement of the considerations supporting the Bonzuit Tcller rule can be found in a recent decision of the Board holding that denial to the tunion of access on company time and premises where the employer had a broad but privileged no-solicitation rule constituted an unfair labor practice and cause for a new election. ${ }^{112}$

Respondent seized for itself the most advantageous circumstances in which to present to employees its side of the organizational question. It spoke to them in massed assemblies during working time, thus gatining the not inconsiderable benefit flowing from the utilization of the employment relationship for such purposes, and ensuring that its message would reach all of its employees in the most carefully thought out and coherent form for maximum effectiveness. At the same time it relegated the union and its employee supporters to relatively catch-as-catch-can methods of rebuttal, such as home visits, advertised meetings on the employees' own time, telephone calls, letters, and the various mass media of communication....

The place of work is the one place where all employees involved are sure to be together. Thus it is the one place where they can all discuss with each other the advantages and disadvantages of organization, and lend each other support and encouragement. Such full discussion lies at the very heart of the organizational rights guaranteed by the Act. . . . It is only where opportunities for such discussion are available, limited, of course, by the need to maintain production, order and discipline, that the

110. 107 N.L.R.B. at 405-07.

111. See, e.g., Bonwit Teller, 96 N.L.R.B. at 614-15; Livingston Shirt Corp., 107 N.L. R.B. at 406-07.

112. May Department Stores, 136 N.L.R.B. No. 71 (1962), 49 L.R.R.M. 1862. 
election procedures established in the Act can be expected to produce the peaceful resolution of representation questions on the basis of a free and informed choice. ${ }^{113}$

The "catch-as-catch-can" forms of access available to the union which the Board found inadequate in May Department Stores are probably all a union will have in most organizational campaigns. ${ }^{114}$ Where such an imbalance exists, the only alternative to the requirements of the Bonwit Teller presumption is to allow a highly effective one sided presentation of views to the employees. Such a situation does not seem to comport with the statutory policy guaranteeing employees a reasoned choice, regardless of whether the statute is or is not neutral to collective bargaining. Because of the fundamental importance of this statutory policy and because of the mandate of the Supreme Court to the Board to ensure equal access, the Board would seem justified in resolving this conflict in favor of resurrecting the Bonwit Teller doctrine. ${ }^{110}$

More directly related to the benefits of debate in ensuring a reasoned choice would be a procedure attempting to guarantee that the employees receive both employer and union views on the issue of organization. The Bonwit Teller doctrine, even if resurrected, does not assure a full presentation of views, for the employer must first address the employees in certain circumstances before it comes into operation. If Bonwit Teller is not reinstated, the need for another effective media of communication is accentuated. The procedure suggested here, which may be termed the Oregon pamphlet plan, is based upon that state's practice of mailing to all voters at a specified time before each election state subsidized pamphlets setting forth the arguments supporting and opposing candidates and referendum proposals. ${ }^{110}$ The arguments are published as submitted by party committees, independent candidates, individuals filing initiative petitions, and any person opposing candidacies or referendum measures. Studies of

113. 49. L.R.R.M. at 1864. The opinion says further:

Where such discussion is not allowed, the normal channels of communication become clogged and lose their effectiveness. ... . The balance in 'opportunities for organizational communication' is destroyed by an employer's utilization of working time and place for its antiunion campaign. ... Only by [acceding to the Union's request to address the employees under similar circumstances] could the [employer] maintain the balance which the Supreme Court deemed so important a factor in this area.

Id. at 1864-65.

114. For a thorough analysis of the forms of access available to unions and management and their effectiveness see Note, Union Right of Reply to Employer On-fhe-Job Spccehes: The NLRB Takes $A$ New Approach, 61 Y ALE L.J. 1066, 1074-78 (1952).

115. This choice among competing values seems well within the competence and authority of the Board, involving as it does those considerations of labor-management relations which are its statutory charge-and, indeed, considerations which the Supreme Court has ordered in such a way as to suggest just this resolution.

116. 23 Ore. R. Stat. 255 (1961). The pamphlet is used in California to inform voters about ballot measures, 29 CAL. ELEC. CoDE $\$ \S 3567-74$ (1961), and in North Dakota to inform voters about ballot measures and candidates, 3 N. DAK. CODE ANN., tit. 16, ch. 16-19 (1960). The discussion here of voter pamphlets is considerably indebted to KELLEr, of, cit. supra note 48 , at 41 . 
the pamphlet's effectiveness indicate that it "is often the most widely read publication of the campaign"117__."no other document . . . plays . . . such an important role in ... 'the decision-making process." "118 The pamphlet's official character and the fact that the voter can see in juxtaposition the presentations of both sides give it a special claim to the voter's attention.

This method of communication could be applied to organizational campaigns without serious difficulty. Shortly after the first week following a Board order for a representation election, ${ }^{110}$ the Regional Director of the NLRB would mail to the employees a pamphlet presenting the arguments for and against organization-arguments written by the parties and subject to no editing or revision by the Regional Director. ${ }^{120}$ Similarly, on the day before the election, the Regional Director would distribute another pamphlet, ${ }^{121}$ prepared in the same way except that before the statements are published each party will have an opportunity to see the other's and incorporate rebuttal in his own. As op posed to political campaigns where the wealth of the candidates is often grossly unequal, ${ }^{122}$ it is appropriate in representation campaigns that the full cost of the publication and its distribution be borne by the parties. ${ }^{123}$ In order to insure maximum opportunity for deliberation the Peerless Plyzood rule, which prohibits speeches during working hours within 24 hours of the election, ${ }^{124}$ should be extended to bar any campaign activity after the distribution of the second pamphlet. Extending Peerless Plywood would vest the pliblication with even more considerable influence, for it would be the last and freshest communication in the hands of the employee, the likely foctus of the final moments of his decision. The employer and union will, of course, be free to campaign at any time other than after the distribution of the second pamphlet and in whatever other manner they choose.

117. See KelLEY, op. cit. sitpra note 48 , at 41 .

118. Id. at 42. In his discussion of the effectiveness of the pamphlet Kelley cites this explanation: "The key reason ... or [its] effectiveness ... is that it affords the voter an opportunity to study both sides of the case, presented simultaneously in the same document, under official auspices." Id. at 42 n.29.

119. The customary order for an election directs that it be held within thirty days. 26 NLRB ANn. Rep. 69 (1961).

120. This is the practice in California and North Dakota. See supra note 116. This procedure is quite as appropriate here for reasons of convenience as well as for the stibstantial reason that there should be no censor in election campaigns. See supra note 78. The usual remedies will be available if the pamphlet is used for cocrcive statements or for egregious misrepresentation.

121. The second pamphlet might well be distributed by the Board agents who are present at the election. 26 NLRB ANN. REP. 71 (1961).

122. Candidates in Oregon pay a statutory sum that amounts to onc-third of the cost; the state pays the other two-thirds. KEILEY, op. cit. supra note 48 at 37.

123. This is not to say that the parties to a representation election are equally wealthy but only that each is likely to be above the financial threshold necessary to support the cost of such a publication.

124. 107 N.L.R.B. 427 (1953). 
The obligation of the Board to ensure that the employees make their choice under "conditions as nearly ideal as possible"125 - the core of the statutory policy-and the Supreme Court's solicitude in United Steclicurkers for a balance of opportunities for organizational communication ${ }^{120}$ would seem to provide ample authority for establishing this procedure. Failure by either party to comply should result in a presumption that the conditions surrounding the election were not conducive to a reasoned choice. And the failure of a party to publish or to rebut the presumption should result, upon a motion of the other party, in an order invalidating the election. To a non-publishing but victorious employer the consequences of such invalidation are not only the increased possibility of another organizational campaign by the defeated union or by another union, bat also a loss of the employer's right to be free from organizational picketing for a year and from other picketing with whatever secondary effects may accompany it. To a non-publishing but victorious union invalidation means another organizational effort. Since these risks will most often exceed the cost to the parties of publishing, the sanction of invalidation, albeit a limited one, may be expected to work compliance with the rule.

Both the pamphlet procedure and the Bonwit Teller rule seem particularly effective in assuaging the problem of the race issue, for they enable the union to reach the employees, responding to the employer's statements in se, or elaborating the various benefits of union organization in as vivid detail as the employer portrayed the alleged racial consequences. These procedures mitigate the effect of misrepresentation and distortion; the opportunity for immediate and direct challenge makes such efforts risky and minimizes the chance of their being believed. ${ }^{127}$ It may well be that the studies indicating that biased persons shut out anti-prejudice propaganda, that they actually fail to see or to hear such propaganda, ${ }^{128}$ are applicable here and that such phenomena will hinder the persuasive efforts of the unions. Nevertheless, if the statutory guarantees of employee choice are to have force, ${ }^{120}$ and if the union's racial policies are relevant to employee values, ${ }^{130}$ it is not appropriate that the discussion of the union's policy on racial integration should be entirely removed from the election $;^{131}$ rather the discussion should be an open and adversary one.

The presumptions suggested here seem clearly warranted by the objective of securing for the employees an opportunity to make a deliberate choice in the presence of full and accurate information and argument. They lend some form to the process of balancing the opportunities for organizational communication,

125. General Shoe Corp., 77 N.L.R.B. 124 at 127 (1948).

126. 357 U.S. at 364 .

127. See text following note 98 supra.

128. See authorities cited at note 52 supra.

129. See text accompanying notes 75-87 supra.

130. Ibid.

131. Indeed, even if the parties were prevented from raising the issue, it would likcly be present in employee discussion. 
providing both administrative convenience and predictable standards for union and employer conduct. Although irrational and undesirable factors will contintuc to influence employee choice, the very best that can be done, so long as the objective is a free and reasoned choice, and not a determined one, is to ensure that the discussion is fully informed and that the decision which follows is reasonably deliberative. 